\title{
Association of a structural variant within the SQSTM1 gene with amyotrophic lateral sclerosis
}

Julia Pytte, BSc (Hons), Ryan S. Anderton, PhD, Loren L. Flynn, PhD, Frances Theunissen, MBiomedSc, Leanne Jiang, BSc (Hons), lanthe Pitout, PhD, lan James, PhD, Frank L. Mastaglia, MD, Ann M. Saunders, PhD, Richard Bedlack, MD, PhD, Teepu Siddique, MD, Nailah Siddique, RN, Msn, and P. Anthony Akkari, PhD

Neurol Genet 2020;6:e406. doi:10.1212/NXG.0000000000000406

\author{
Correspondence \\ Prof. Akkari \\ Anthony.akkari@perron.uwa.edu.au
}

\begin{abstract}
\section{Objective}

As structural variations may underpin susceptibility to complex neurodegenerative diseases such as amyotrophic lateral sclerosis (ALS), the objective of this study was to investigate a structural variant (SV) within sequestosome 1 (SQSTMI).
\end{abstract}

\section{Methods}

A candidate insertion/deletion variant within intron 5 of the SQSTM1 gene was identified using a previously established SV evaluation algorithm and chosen according to its subsequent theoretical effect on gene expression. The variant was systematically assessed through PCR, polyacrylamide gel fractionation, Sanger sequencing, and reverse transcriptase PCR.

\section{Results}

A reliable and robust assay confirmed the polymorphic nature of this variant and that the variant may influence SQSTM1 transcript levels. In a North American cohort of patients with familial ALS (fALS) and sporadic ALS (sALS) $(\mathrm{n}=403)$ and age-matched healthy controls $(\mathrm{n}=562)$, we subsequently showed that the SQSTM1 variant is associated with fALS $(p=0.0036)$, particularly in familial superoxide dismutase 1 mutation positive patients $(p=0.0005)$, but not with patients with sALS $(p=0.97)$.

\section{Conclusions}

This disease association highlights the importance and implications of further investigation into SVs that may provide new targets for cohort stratification and therapeutic development.

From the University of Western Australia (J.P., R.S.A., L.L.F., F.T., L.J., F.L.M., P.A.A.), Centre for Neuromuscular and Neurological Disorders, Crawley; Perron Institute for Neurological and Translational Science (.P., R.S.A., L.L.F., F.T., L.J., I.P., F.L.M., P.A.A.), Nedlands; University of Notre Dame Australia (R.S.A.), School of Health Sciences; University of Notre Dame Australia (R.S.A.), Institute for Health Research, Fremantle; Murdoch University (L.L.F., I.P., P.A.A.), Centre for Molecular Medicine and Innovative Therapeutics; Murdoch University, Institute for Immunology and Infectious Diseases (I.J.), Western Australia, Australia; Department of Neurology (R.B.), Duke University School of Medicine, Durham, NC; Zinfandel Pharmaceuticals (A.M.S.), Inc.; Duke University (R.B.), ALS Clinic, Durham, NC; and Departments of Neurology, Pathology and Cell and Molecular Biology (T.S., N.S.), Northwestern University Feinberg School of Medicine, the Les Turner ALS Center and the Northwestern University Interdepartmental Neuroscience Program, Chicago, IL. 


\section{Glossary}

ALS = amyotrophic lateral sclerosis; CI = confidence interval; fALS = familial ALS; GWAS = genome-wide association study; I/ $\mathbf{D}=$ insertion/deletion; $\mathbf{m R N A}=$ messenger RNA; ONS = olfactory neurosphere derived; $\mathbf{O R}=$ odds ratio; $\mathbf{s A L S}=$ sporadic ALS; SOD1 = superoxide dismutase 1; SQSTM1 = sequestosome 1; RT-PCR = reverse transcriptase PCR; SV = structural variant.

A growing body of literature indicates that structural variants (SVs) are important in complex diseases because their role in gene expression and messenger RNA (mRNA) regulation is now emerging. ${ }^{1-4}$ Given the potential implication of SVs in neurodegenerative disorders, ${ }^{5-7}$ an investigation of SVs within associated genes may provide insight toward the pathogenic mechanisms involved and enable the identification of new therapeutic targets.

Mutations in sequestosome 1 (SQSTM1), and aggregation of the SQSTM1-encoded p62 protein, have been identified in patients with amyotrophic lateral sclerosis (ALS) and other neurodegenerative diseases. ${ }^{8-13} \mathrm{P} 62$ is a multifunctional protein that binds ubiquitin and is involved in autophagy, proteasomal degradation of ubiquitinated proteins, mitophagy, and cellular signaling. ${ }^{14-16}$ Variants within SQSTM1 or surrounding SQSTM1 may contribute to the diverse presentation observed between the patients with ALS. How mutations in SQSTM1 influence ALS is not fully understood; however, it is believed that structural changes to the protein may affect adapter function of SQSTM1 to the LC3 protein in the nascent autophagosome and impair autophagy of proteins that are not recyclable by the proteasome. ${ }^{17}$ Other cellular systems may also be affected such as ubiquitin binding and regulation of cellular processes including DNA repair, endocytosis, and signal transduction. ${ }^{8,14}$

In the current study, a potential influential insertion/deletion (I/D) within intron 5 of SQSTM1 was identified using an in silico short SV evaluation algorithm. ${ }^{18}$ Reverse transcriptase PCR (RT-PCR) analysis revealed a link between the I/D and altered transcript levels. An exploratory association study in a sporadic and familial North American ALS cohort established an association with familial ALS (fALS), particularly superoxide dismutase 1 (SOD1) mutation-positive patients but not sporadic ALS (sALS). We further examined whether this SV was associated with age of disease onset and duration in SOD1 mutation-positive patients and found no statistically significant association.

\section{Methods}

\section{Standard protocol approvals, registrations, and patient consents}

This study was approved by the ethical standards of the relevant institutional review board, the Human Research Ethics Committee of the University of Western Australia (RA/4/20/ 5308). Participants were enrolled after informed consent was obtained. Clinical data were collected according to the Health
Insurance Portability and Accountability Act Standards of Confidentiality and Disclosure and approved by the Northwestern University institutional review board (STU0012722/ CR5_STU00012722) and the Duke University institutional review board (PRO00040665/323682). All patients were diagnosed by board-certified neurologists and met the revised El Escorial World Federation of Neurology criteria for diagnosis with ALS. ${ }^{19}$

\section{SV identification}

An SV evaluation algorithm was used to locate the variant within the gene, SQSTM1. ${ }^{18}$ Detailed methods are described in the supplementary material (see e-methods, links.lww. com/NXG/A229).

\section{PCR amplification and Sanger sequencing}

Detailed methods are described in the supplementary material. Sequences of all primers used for this study are outlined in table e-1 (links.lww.com/NXG/A229).

\section{Olfactory neurosphere-derived cells}

Culturing information can be found in the supplementary data.

\section{RT-PCR and densitometry}

Detailed methods are described in the supplementary material. Sequences of all primers used for this study are detailed in table e-1 (links.lww.com/NXG/A229).

\section{ALS and healthy control participants}

A cohort of 196 fALS, 207 sALS, and 562 healthy control participants were recruited into the Neurologic Diseases Registry, Northwestern University, Chicago, USA, and Duke University, North Carolina, USA. The 196 fALS cases from Northwestern University belong to 74 different families with possible within-family genetic correlations. The mutation data for all fALS patients are detailed in table e- 2 (links.lww.com/NXG/A229).

\section{Statistics}

Data are reported as mean \pm SD where appropriate. Statistical differences in genotype proportions for independent cases were assessed using Pearson $\chi^{2}$ test with Yates correction. Proportions and ages of onset involving familial groups were analyzed using the mixed effects regression models to account for possible within-family correlations. Durations were analyzed using Cox proportional hazards models with clustering to account for the correlations. Analyses were carried out in IBM SPSS Statistics version 25.0 (IBM Co., Armonk, NY) and R version 3.4.3 (R Foundation for Statistical Computing, Vienna, Austria). 


\section{Data availability}

Study data for the primary analyses presented in this report are available on reasonable request from the corresponding author.

\section{Results}

\section{Identification of a polymorphic variant within the SQSTM1 gene}

An SV evaluation algorithm was used to identify the genetic variant located within SQSTM1. The identified cytosine adenine adenine adenine (CAAA) I/D within intron 5 of SQSTM1 was evaluated on the NCBI database; although the region had been previously reported (NC_0000005.0), no disease associations were established. The recorded NCBI data demonstrated uncertainty to its polymorphic nature; currently, the region is recorded as a series of insertion/deletions of varying length, with no allelic frequency data. Conventional polyacrylamide gel electrophoresis revealed a biallelic variant, consisting of a heterozygous I/D genotype in lanes 2,3 , and 7 , a homozygous D/ D genotype in lanes 4 and 8 , and a homozygous I/I genotype in lanes 5, 6, and 9 (figure 1A). Sanger sequencing confirmed that the I allele contained a CAAA insertion when compared with the $\mathrm{D}$ allele (figure $1 \mathrm{~B})$. To determine the effect of the CAAA SV on SQSTM1 expression, SQSTM1 was assessed in a panel (n $=3$ ) of olfactory neurosphere-derived (ONS) cells obtained from the healthy controls. Semiquantitative RT-PCR revealed a stepwise increase in the level of SQSTM1 transcript, with the I/I genotype yielding the lowest levels and the $\mathrm{I} / \mathrm{D}$ and $\mathrm{D} / \mathrm{D}$ genotypes producing a 1.77 -fold and 2.47 -fold relative increase in SQSTM1 transcript, respectively (figure 1C).

\section{The SQSTM1 variant is associated with fALS}

Following the identification of the CAAA I/D variant, we proceeded to determine the variant frequency in a cohort of 196 fALS patients, 207 sALS patients, and 562 healthy agematched controls. The characteristics of the study participants are summarized in table 1 , including sex, age, disease duration, and family history of each cohort. Of the ALS cohort, patients with familial mutations $(48.6 \%)$ were further grouped by affected gene, specifically C9orf 72 (2.5\% of patients with ALS), SOD1 (41.4\% of patients with ALS), or TDP-43 (4.7\% of patients with ALS).

There was no difference in the frequency of the SQSTM1 variant observed between healthy controls and sALS cases $\left(\chi^{2}\right.$ $=0.032, \mathrm{df}=2, p=0.984$, odds ratio $[\mathrm{OR}]=0.974,95 \%$ confidence interval $[\mathrm{CI}]: 0.660,1.436)$. However, there was a difference in SQSTM1 variant frequency observed between healthy controls and fALS patients $\left(\chi^{2}=12.791, \mathrm{df}=2, p=\right.$ $0.002, \mathrm{OR}=1.79,95 \% \mathrm{CI}: 1.250,2.562$ assuming independence of cases), with the homozygous (I/I) genotype over-represented in the fALS cohort (33.2\%) when compared with the controls (21.7\%). When analyzed using mixed effects regression models to account for possible within-family correlations, the (I/I) association remained both genotypical and allelical ( $p=0.013$ and $p=0.0036$, respectively, table 2 ). This
Figure 1 Characterization of the SQSTM1 variant
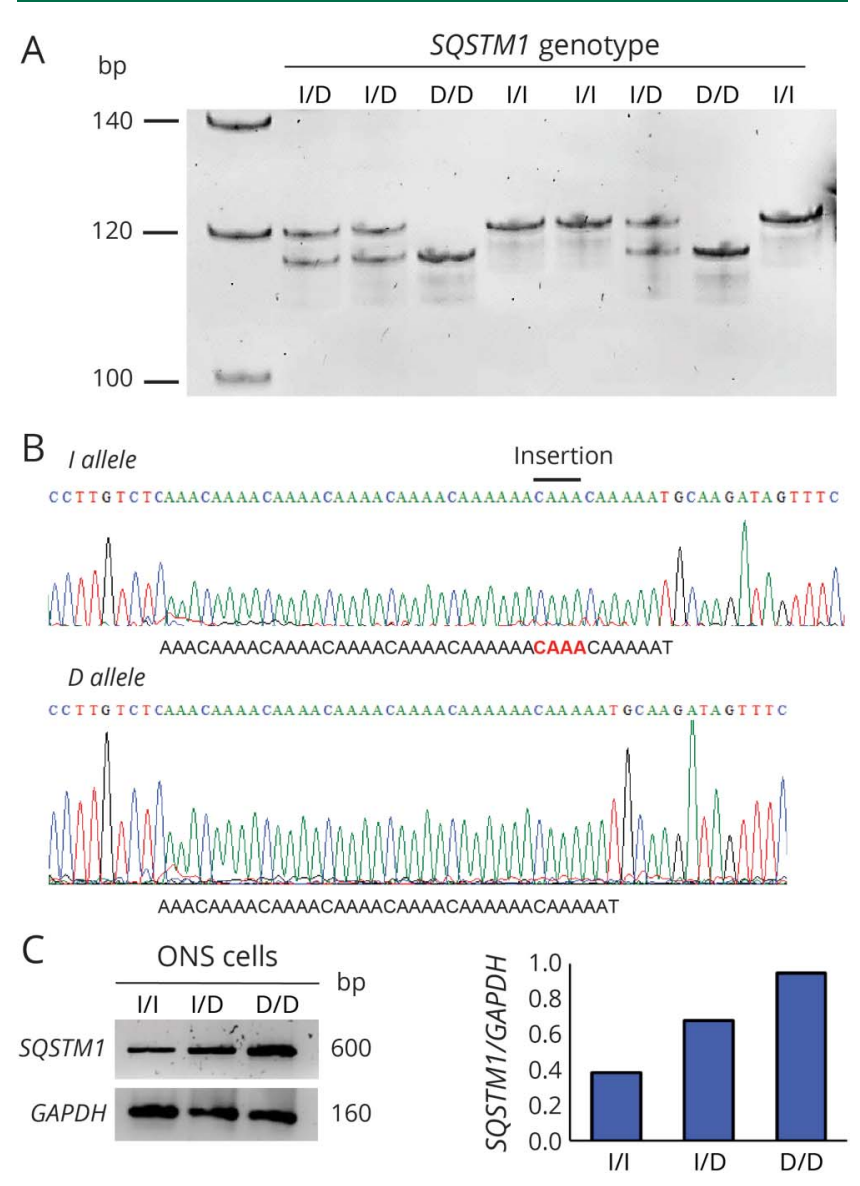

(A) PCR and native polyacrylamide gel electrophoresis across a random selection of control DNA samples and compared against a 100bp ladder. (B) Sanger sequencing of the I allele and D allele. (C) SQSTM1 transcript levels of SQSTM1 exon 4-7 analyzed using RT-PCR on RNA from a panel of control ONS cells. Relative densitometry was calculated with SQSTM1 transcript signal standardized to each respective GAPDH signal. GAPDH = glyceraldehyde 3-phosphate dehydrogenase; $\mathrm{l} / \mathrm{D}$ = insertion/deletion; ONS = olfactory neurosphere derived cells; RT-PCR = Reverse transcriptase PCR; SQSTM1 = sequestosome 1.

SQSTM1 association was stronger when examining the subset of fALS patients carrying mutations in SOD1 $\left(\chi^{2}=16.754\right.$, $\mathrm{df}=2, p=0.0002, \mathrm{OR}=1.869,95 \% \mathrm{CI}: 1.281,2.726$ assuming independent cases). When accounting for family structures, the SQSTM1 variant was strongly associated with patients carrying a SOD1 mutation both genotypically and allelically $(p=0.001$ and $p=0.0005$, respectively) (table 2 ). When analyzed with SOD1-A5V mutation-positive patients excluded, the strong SOD1 association remains $\left(\chi^{2}=6.801, p<0.009\right.$, OR $=1.830$, 95\% CI: $1.157,2.896)$.

The SQSTM1 variant is not associated with age at onset of disease or survival in patients with SOD1.

To determine if the SQSTM1 variant is associated with SOD1 mutation-positive ALS patient outcomes, age at onset and survival were analyzed. There was no association observed between the age at onset in patients with the I/I (Mean Rank = 87.25), I/D (Mean Rank = 76.40), or D/D (Mean Rank = 
Table 1 Characteristics of patients and healthy control participants

\begin{tabular}{lll}
\hline & \multicolumn{2}{l}{ Mean (SD) or $\mathbf{n}$} \\
\cline { 2 - 3 } Variable & $\begin{array}{l}\text { Patients } \\
(\mathrm{n}=\mathbf{4 0 3})\end{array}$ & $\begin{array}{l}\text { Controls } \\
(\mathrm{n}=\mathbf{5 6 2})\end{array}$ \\
\hline Sex & & \\
\hline Male & 208 & 296 \\
\hline Female & 195 & 266 \\
\hline Age (y) & $52.38(12.99)$ & $49.37(12.56)$ \\
\hline Disease duration (mo) & $43.21(46.98)$ & - \\
\hline Family history & & - \\
\hline Sporadic & 207 & - \\
\hline Familial & 196 & \\
\hline
\end{tabular}

84.43) genotypes ( $p=0.2$, mixed model regression, figure $2 \mathrm{~A}$ ). Survival curves were generated to compare durations of each genotypic group (figure 2B). No association was observed between patients carrying each genotype and their survival after taking into account of familial correlations via a clustered Cox regression $(p=0.55)$.

\section{Discussion}

A growing body of literature has highlighted SVs, their abundance throughout the human genome, and their potential role in the pathogenesis of ALS and other neurodegenerative diseases. ${ }^{20-24} \mathrm{SVs}$ are responsible for greater diversity at the nucleotide level between 2 human genomes than any other form of genetic variations and are three-fold more likely to associate with genome-wide association studies (GWASs) signals than single nucleotide polymorphisms (SNPs). ${ }^{20} \mathrm{SVs}$ that remain cryptic to current sequencing algorithms are likely to account for disease-causing variation in unsolved Mendelian disorders and missing heritability in complex disorders. ${ }^{20,23}$ SVs may affect gene expression and therefore may play an important but understudied role in disease susceptibility. ${ }^{20,25}$ Recent discoveries of SVs as informative disease risk markers for rare genetic disorders provide compelling evidence for ongoing investigation into the association between SVs and rare genetic diseases. ${ }^{26-30}$ The novel bioinformatics SV evaluation algorithm tool prioritizes potential functional/causal SVs within candidate regions identified using GWAS. ${ }^{18}$ In ALS and all rare genetic diseases, these highly polymorphic markers are often overlooked, largely because of the limitations in the current gene sequencing platforms such as next-generation sequencing and GWAS, which are primarily designed to detect SNPs.

Two direct lines of evidence link SQSTM1 to ALS: the first through etiology on account of mutations associated with ALS and second through pathology, where p62 immune-reactive
Table 2 Association of SQSTM1 variant and ALS disease status

\begin{tabular}{|c|c|c|c|}
\hline SALS & Control $n(\%)$ & sALS $n(\%)$ & $p$ Value \\
\hline \multicolumn{4}{|c|}{ SQSTM1 CAAA variant } \\
\hline $1 / I$ & $122(21.7)$ & $44(21.3)$ & \\
\hline I/D & $292(52.0)$ & $109(52.7)$ & 0.98 \\
\hline$D / D$ & $148(26.3)$ & $54(26.1)$ & \\
\hline I allele & 536 & 197 & \\
\hline D allele & 588 & 217 & 0.97 \\
\hline Familial ALS & Control $n(\%)$ & fALS $n(\%)$ & $p$ Value \\
\hline \multicolumn{4}{|c|}{ SQSTM1 CAAA variant } \\
\hline $1 / I$ & $122(21.7)$ & $65(33.2)$ & 0.0013 \\
\hline I/D & $292(52.0)$ & $97(49.5)$ & 0.50 \\
\hline$D / D$ & $148(26.3)$ & $34(17.3)$ & 0.08 \\
\hline I allele & 536 & 227 & \\
\hline D allele & 588 & 165 & 0.0036 \\
\hline $\begin{array}{l}\text { SOD1 mutatio } \\
\text { positive }\end{array}$ & Control $n(\%)$ & SOD1 n (\%) & $p$ Value $^{a}$ \\
\hline \multicolumn{4}{|c|}{ SQSTM1 CAAA variant } \\
\hline $1 / I$ & $122(21.7)$ & $57(34.1)$ & 0.001 \\
\hline I/D & $292(52.0)$ & $87(52.1)$ & 0.99 \\
\hline $\mathrm{D} / \mathrm{D}$ & $147(26.3)$ & $23(13.8)$ & 0.014 \\
\hline I allele & 536 & 201 & \\
\hline D allele & 588 & 133 & 0.0005 \\
\hline
\end{tabular}

Abbreviations: $A L S=$ amyotrophic lateral sclerosis; fALS = familial ALS I/D = insertion/deletion; sALS = sporadic ALS; SQSTM1 = sequestosome 1. ${ }^{a}$ Each row compared using random effects to account for familial correlation.

inclusions are found in virtually all forms of ALS and ALSfrontotemporal dementia. ${ }^{8}$ We now provide a third link of SQSTM1 variants to the fALS. SQSTM1-encoded p62 protein is a key scaffolder involved in cellular signaling and protein degradation through the autophagosome-lysosome system. ${ }^{17}$ SQSTM1/p62 mutations may confer a toxic gain of function through protein interactions, leading to dysregulation of cell signaling pathways, protein misfolding, and aggregation. ${ }^{8}$ Evidence for this in the literature suggests parallels between $\mathrm{p} 62$ and other proteins associated with neurodegeneration, including SOD1-linked ALS, C9orf72, ubiquilin 2, TDP-43, FUS, optineurin, beta-amyloid, $\alpha$-synuclein, and tau. ${ }^{8,31}$ Owing to its role in protein degradation, overexpression of $\mathrm{p} 62$ has been shown to be protective in some neurodegenerative animal models, but overexpression in a SOD1 ALS model was found to accelerate disease onset. ${ }^{32-34}$ Taken together, these studies suggest that a fine balance in p62 levels is required for optimal signaling and protein clearance. Consequently, small changes in 
Figure 2 Association of the SQSTM1 variant with age at onset of disease and survival
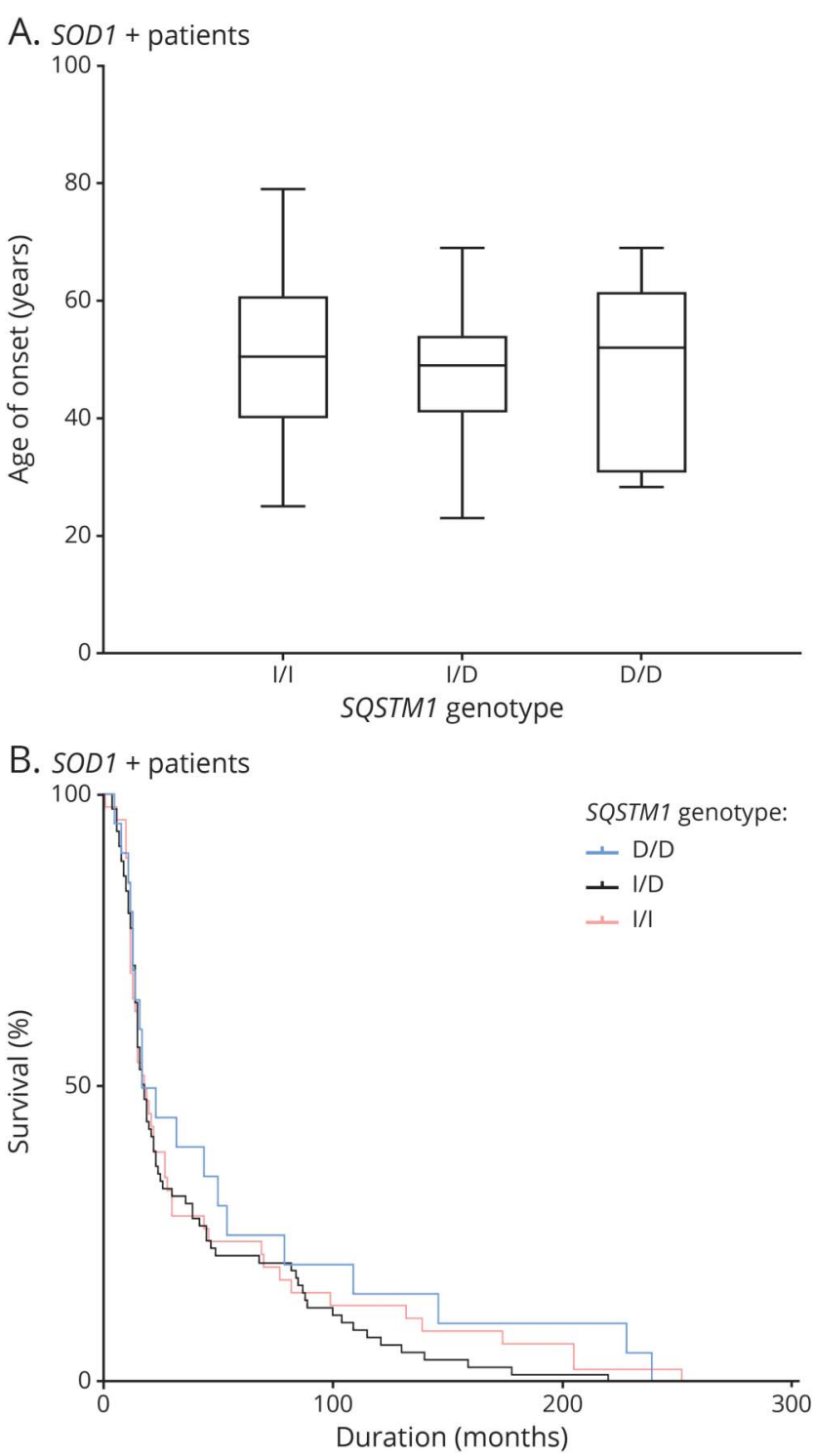

(A) The median and distribution of age at onset (years) of SOD1 mutationpositive patients with ALS $(n=167)$ grouped by each SQSTM1 variant genotype. (B) Kaplan-Meier survival curves of SOD1 mutation-positive patients, comparing the SQSTM1 genotypes assuming independent measurements. A robust log-rank test accounting for familial correlation was performed to assess any association between the groups. Survival was measured in months from ALS diagnosis until death. ALS = amyotrophic lateral sclerosis; SOD1 = superoxide dismutase $1 ;$ SQSTM1 = sequestosome 1.

the level of $\mathrm{p} 62$ expression, which may be produced by variants such as the SQSTM1 intron $5 \mathrm{I} / \mathrm{D}$, could tip the balance of p62 expression, contributing to the disease. Previously identified mutations within SQSTM1 have been associated with ALS. ${ }^{35,36}$ As such, it has been suggested that these mutations may have a direct role in ALS pathogenesis, presenting as an important target for future therapy. ${ }^{8}$

In this study, we hypothesized that structural variations in SQSTM1 may uncover novel susceptibility factors that underpin this disease. SQSTM1 mutations, and p62 aggregation, have been reported not only in ALS but also in other complex neurodegenerative diseases, including Parkinson disease, Paget disease of bone, Alzheimer disease and frontotemporal dementia. $^{8-13}$ A semiquantitative assessment of the mRNA expression revealed a difference in SQSTM1 transcript levels in the ONS cells carrying each genotype. Neural tissue derived from olfactory mucosa, such as primary ONS cells, provide informative cellular models for neurodegenerative diseases. Primary ONS cells are neural progenitor cells and more accurately reflect motor neuron cellular function than fibroblasts and PBMCs, and unlike postmortem brain tissue, they can be isolated from living patients. ${ }^{37,38}$ As such, the altered SQSTM1 transcript levels observed in the ONS cells with the I/I genotype may be reflective of altered SQSTM1 expression in motor neurons. Although this result requires validation in a larger sample size, it does suggest some level of regulation by the SV on SQSTM1 transcript expression. This may be due to altered transcription efficiency, splicing, or transcript stability, potentially translating to altered protein expression that may contribute to disease pathologies.

An evaluation of the SQSTM1 variant within a cohort of 403 patients with ALS and 562 healthy age-matched controls revealed an association with fALS disease risk, but not age of disease onset or disease severity. Replications in additional fALS cohorts are necessary to truly elucidate the nature of this variant. Causality has been reported between ALS and SQSTM1 variants rs796051870, rs776749939, rs796052214, and as such, the ongoing investigation between ALS and SQSTM1 gene variants is necessary. ${ }^{8,39,40} \mathrm{P} 62$ has previously been reported as overexpressed and accumulated in inclusions of sporadic inclusion body myositis, reinforcing its importance in neurodegenerative diseases. ${ }^{12} \mathrm{We}$ anticipate that as additional SVs are identified, these will further stratify other relevant disease phenotypes such as age at onset, duration, and disease progression.

\section{Acknowledgment}

The authors are deeply indebted to the late Allen D. Roses, $\mathrm{PhD}$, who provided mentorship to several of the authors and who originally conceptualized and initiated this research. The authors would also like to thank the contribution of Prof. Alan Mackay Sim and Prof. George Mellick (Griffith University, Institute for Drug Discovery) for the generous gift of the ONS cell cultures. The study was in part funded by NIH grants to TS (NS050641, NS046535), the Les Turner ALS Foundation/ Herbert C. Wenske Foundation Professorship and the Les Turner ALS Research and Patient Care Center.

\section{Study funding}

The study was funded by research support from the Perron Institute for Neurologic and Translational Science and the Les Turner Foundation for ALS. The funders have no role in the design of the study and collection, analysis, decision to publish, interpretation of data, or preparation of the manuscript. 
Dislosure

Disclosures available: Neurology.org/NG.

\section{Publication history}

Received by Neurology: Genetics July 19, 2019. Accepted in final form January 23, 2020.

Appendix Authors

\begin{tabular}{lll}
\hline Name & Location & Contribution \\
\hline Julia Pytte, & The Perron Institute for & $\begin{array}{l}\text { Acquisition of the data, } \\
\text { BSc (Hons) }\end{array}$ \\
& $\begin{array}{l}\text { Neurological and } \\
\text { Translational Science, } \\
\text { Nedlands, Australia }\end{array}$ & $\begin{array}{l}\text { interpretation, } \\
\text { statistical analysis, and } \\
\text { critical revision of the } \\
\text { manuscript for } \\
\text { important intellectual } \\
\text { content }\end{array}$ \\
& &
\end{tabular}

\begin{tabular}{ll}
\hline Ryan S. & The Perron Institute for \\
Anderton, & Neurological and \\
PhD & Translational Science, \\
& Nedlands, Australia
\end{tabular}

Study concept and design, statistical analysis, study supervision, and critical revision of the manuscript for important intellectual content

\begin{tabular}{lll}
\hline Loren L. & Murdoch University, & Study concept and \\
Flynn, PhD & Murdoch, Australia & design, analysis and \\
& interpretation, study \\
& supervision, and critical \\
& revision of the \\
& manuscript for \\
& important intellectual \\
& content
\end{tabular}

\begin{tabular}{ll}
\hline Frances & The Perron Institute for \\
Theunissen, & Neurological and \\
MBiomedSc & Translational Science, \\
& Nedlands, Australia
\end{tabular}

Analysis and interpretation and critical revision of the manuscript for important intellectual content

\begin{tabular}{ll}
\hline Leanne Jiang, & The Perron Institute for \\
BSc (Hons) & Neurological and \\
& Translational Science, \\
& Nedlands, Australia
\end{tabular}

Analysis and interpretation and critical revision of the manuscript for important intellectual content

\begin{tabular}{ll}
\hline $\begin{array}{l}\text { Ianthe Pitout, } \\
\text { PhD }\end{array}$ & $\begin{array}{l}\text { The Perron Institute for } \\
\text { Neurological and } \\
\text { Translational Science, } \\
\text { Nedlands, Australia }\end{array}$ \\
\hline $\begin{array}{l}\text { Ian James, } \\
\text { PhD }\end{array}$ & $\begin{array}{l}\text { Murdoch University, } \\
\text { Murdoch, Australia }\end{array}$
\end{tabular}

Study concept and design and acquisition of the data

Statistical analysis and critical revision of the manuscript for important intellectual content

\begin{tabular}{lll}
\hline $\begin{array}{l}\text { Frank } \\
\text { Mastaglia, } \\
\text { MD }\end{array}$ & $\begin{array}{l}\text { The Perron Institute for } \\
\text { Neurological and } \\
\text { Translational Science, } \\
\text { Nedlands, Australia }\end{array}$ & $\begin{array}{l}\text { Critical revision of the } \\
\text { manuscript for } \\
\text { important intellectual } \\
\text { content }\end{array}$ \\
\hline $\begin{array}{l}\text { Ann M. } \\
\text { Saunders, } \\
\text { PhD }\end{array}$ & $\begin{array}{l}\text { Duke University, Durham, } \\
\text { NC }\end{array}$ & $\begin{array}{l}\text { Study concept and } \\
\text { design and critical } \\
\text { revision of the } \\
\text { manuscript for } \\
\text { important intellectual } \\
\text { content }\end{array}$ \\
\hline
\end{tabular}

Appendix (continued)

\begin{tabular}{|c|c|c|}
\hline Name & Location & Contribution \\
\hline $\begin{array}{l}\text { Richard } \\
\text { Bedlack, MD, } \\
\text { PhD }\end{array}$ & $\begin{array}{l}\text { Duke University, Durham, } \\
\text { NC }\end{array}$ & $\begin{array}{l}\text { Study concept and } \\
\text { design, acquisition of } \\
\text { the data, and critical } \\
\text { revision of the } \\
\text { manuscript for } \\
\text { important intellectual } \\
\text { content }\end{array}$ \\
\hline $\begin{array}{l}\text { Teepu } \\
\text { Siddique, MD, } \\
\text { DSc (hc), } \\
\text { FAAN }\end{array}$ & $\begin{array}{l}\text { Northwestern University, } \\
\text { Evanston, IL }\end{array}$ & $\begin{array}{l}\text { Study concept and } \\
\text { design, acquisition of } \\
\text { the data, and critical } \\
\text { revision of the } \\
\text { manuscript for } \\
\text { important intellectual } \\
\text { content }\end{array}$ \\
\hline $\begin{array}{l}\text { Nailah } \\
\text { Siddique, RN, } \\
\text { Msn }\end{array}$ & $\begin{array}{l}\text { Northwestern University, } \\
\text { Evanston, IL }\end{array}$ & $\begin{array}{l}\text { Study concept and } \\
\text { design and critical } \\
\text { revision of the } \\
\text { manuscript for } \\
\text { important intellectual } \\
\text { content }\end{array}$ \\
\hline $\begin{array}{l}\text { P. Anthony } \\
\text { Akkari, PhD }\end{array}$ & $\begin{array}{l}\text { The Perron Institute for } \\
\text { Neurological and } \\
\text { Translational Science, } \\
\text { Crawley, Australia }\end{array}$ & $\begin{array}{l}\text { Study concept and } \\
\text { design, acquisition of } \\
\text { data, analysis and } \\
\text { interpretation, and } \\
\text { critical revision of the } \\
\text { manuscript for } \\
\text { important intellectual } \\
\text { content and study } \\
\text { supervision }\end{array}$ \\
\hline
\end{tabular}

\section{References}

1. Chakravarti A, Kapoor A. Mendelian puzzles. Science 2012;335:930-931.

2. Feuk L, Carson AR, Scherer SW. Structural variation in the human genome. Nat Rev Genet 2006;7:85-97.

3. Stankiewicz P, Lupski JR. Structural variation in the human genome and its role in disease. Annu Rev Med 2010;61:437-455.

4. Lupski JR. Structural variation mutagenesis of the human genome: impact on disease and evolution. Environ Mol Mutagen 2015;56:419-436.

5. Lyall DM, Royle NA, Harris SE, et al. Alzheimer's disease susceptibility genes APOE and TOMM40, and hippocampal volumes in the Lothian birth cohort 1936. PLoS One $2013 ; 8: e 80513$.

6. Lutz MW, Saul R, Linnertz C, et al. A cytosine-thymine (CT)-rich haplotype in intron 4 of SNCA confers risk for Lewy body pathology in Alzheimer's disease and affects SNCA expression. Alzheimers Dement 2015;11:1133-1143.

7. Linnertz C, Anderson L, Gottschalk W, et al. The cis-regulatory effect of an Alzheimer's disease-associated poly-T locus on expression of TOMM40 and apolipoprotein E genes. Alzheimers Dement 2014;10:541-551.

8. Fecto F, Yan J, Vemula SP, et al. SQSTM1 mutations in familial and sporadic amyotrophic lateral sclerosis. Arch Neurol 2011;68:1440-1446.

9. Rea SL, Majcher V, Searle MS, Layfield R. SQSTM1 mutations-bridging paget disease of bone and ALS/FTLD. Exp Cell Res 2014;325:27-37.

10. Zatloukal K, Stumptner C, Fuchsbichler A, et al. p62 Is a common component of cytoplasmic inclusions in protein aggregation diseases. Am J Pathol 2002;160: 255-263.

11. Lowe J, Blanchard A, Morrell K, et al. Ubiquitin is a common factor in intermediate filament inclusion bodies of diverse type in man, including those of Parkinson's disease, Pick's disease, and Alzheimer's disease, as well as Rosenthal fibres in cerebellar astrocytomas, cytoplasmic bodies in muscle, and mallory bodies in alcoholic liver disease. J Pathol 1988;155:9-15.

12. Nogalska A, Chiara AE, Ae T, et al. p62/SQSTM1 is overexpressed and prominently accumulated in inclusions of sporadic inclusion-body myositis muscle fibers, and can help differentiating it from polymyositis and dermatomyositis. Acta Neuropathol 2009;118:407-413.

13. Kwok CT, Morris A, de Belleroche JS. Sequestosome-1 (SQSTM1) sequence variants in ALS cases in the UK: prevalence and coexistence of SQSTM1 mutations in ALS kindred with PDB. Eur J Hum Genet 2014;22:492-496.

14. Kirkin V, McEwan DG, Novak I, Dikic I. A Role for ubiquitin in selective autophagy. Mol Cell 2009;34:259-269.

15. Welchman RL, Gordon C, Mayer RJ. Ubiquitin and ubiquitin-like proteins as multifunctional signals. Nat Rev Mol Cell Biol 2005;6:599-609. 
16. Rogov V, Dötsch V, Johansen $T$, Kirkin V. Interactions between autophagy receptors and ubiquitin-like proteins form the molecular basis for selective autophagy. Mol Cell 2014;53:167-178.

17. Pankiv S, Clausen TH, Lamark T, et al. p62/SQSTM1 binds directly to Atg8/LC3 to facilitate degradation of ubiquitinated protein aggregates by autophagy. J Biol Chem 2007;282:24131-24145.

18. Saul R, Lutz MW, Burns DK, Roses AD, Chiba-Falek O. The SSV evaluation system a tool to prioritize short structural variants for studies of possible regulatory and causal variants. Hum Mutat 2016;37:877-883.

19. Brooks BR, Miller RG, Swash M, Munsat TL, World Federation of Neurology Research Group on Motor Neuron Diseases. El Escorial revisited: revised criteria for the diagnosis of amyotrophic lateral sclerosis. Amyotroph Lateral Scler Other Mot Neuron Disord 2000;1:293-299.

20. Chaisson MJP, Sanders AD, Zhao X, et al. Multi-platform discovery of haplotyperesolved structural variation in human genomes. Nat Commun 2019;10:1784.

21. Sudmant $\mathrm{PH}$, Rausch T, Gardner EJ, et al. An integrated map of structural variation in 2,504 human genomes. Nature 2015;526:75-81.

22. Roses $\mathrm{AD}$. Short sequence variations (SSVs) may explain multiplicity of SOD1-SNP mutations in Amyotrophic Lateral Sclerosis. Presented at the 66th Annual Meeting American Society of Human Genetics; October 19, 2016; Vancouver.

23. Roses $\mathrm{AD}$, Akkari PA, Chiba-Falek O, et al. Structural variants can be more informative for disease diagnostics, prognostics and translation than current SNP mapping and exon sequencing. Expert Opin Drug Metab Toxicol 2016;12:135-147.

24. Frazer KA, Murray SS, Schork NJ, Topol EJ. Human genetic variation and its contribution to complex traits. Nat Rev Genet 2009;10:241-251.

25. Li YC, Korol AB, Fahima T, Nevo E. Microsatellites within genes: structure, function, and evolution. Mol Biol Evol 2004;21:991-1007.

26. De Jesus-Hernandez M, Mackenzie IR, Boeve BF, et al. Expanded GGGGCC hexanucleotide repeat in noncoding region of C9ORF72 causes chromosome 9p-Linked FTD and ALS. Neuron 2011;72:245-256.

27. Gijselinck I, Van Langenhove T, van der Zee J, et al. A C9orf72 promoter repeat expansion in a Flanders-Belgian cohort with disorders of the frontotemporal lobar degeneration-amyotrophic lateral sclerosis spectrum: a gene identification study. Lancet Neurol 2012;11:54-65.
28. Renton AE, Majounie E, Waite A, et al. A hexanucleotide repeat expansion in C9ORF72 is the cause of chromosome 9p21-linked ALS-FTD. Neuron 2011;72:257-268.

29. Sproviero W, Shatunov A, Stahl D, et al. ATXN2 trinucleotide repeat length correlates with risk of ALS. Neurobiol Aging 2017;51:178.e-1-178.

30. Roses AD, Lutz MW, Amrine-Madsen H, et al. A TOMM40 variable-length polymorphism predicts the age of late-onset Alzheimer's disease. Pharmacogenomics J 2010;10:375-384.

31. Deng HX, Chen W, Hong ST, et al. Mutations in UBQLN2 cause dominant X-linked juvenile and adult-onset ALS and ALS/dementia. Nature 2011;477:211-215.

32. Doi $\mathrm{H}$, Adachi $\mathrm{H}$, Katsuno $\mathrm{M}$, et al. p62/SQSTM1 differentially removes the toxic mutant androgen receptor via autophagy and inclusion formation in a spinal and bulbar muscular atrophy mouse model. J Neurosci 2013;33:7710-7727.

33. Hadano S, Mitsui S, Pan L, et al. Functional links between SQSTM1 and ALS2 in the pathogenesis of ALS: cumulative impact on the protection against mutant SOD1mediated motor dysfunction in mice. Hum Mol Genet 2016;25:3321-3340.

34. Mitsui S, Otomo A, Nozaki M, et al. Systemic overexpression of SQSTM1/p62 accelerates disease onset in a SOD1 H46R-expressing ALS mouse model. Mol Brain 2018;11:1-16.

35. Gal J, Strom A-L, Kwinter DM, et al. Sequestosome 1/p62 links familial ALS mutant SOD1 to LC3 via a ubiquitin-independent mechanism. J Neurochem 2009;111: 1062-1073.

36. Zhou L, Wang H, Ren H, et al. Bcl-2-dependent upregulation of autophagy by sequestosome 1/p62 in vitro. Acta Pharmacol Sin 2013;34:651-656.

37. Féron F, Perry C, Girard SD, Mackay-Sim A. Isolation of adult stem cells from the human olfactory mucosa. In: Reynolds B, Deleyrolle L, editors. Methods in Molecular Biology. New Jersey: Humana Press; 2013:107-113.

38. Matigian N, Abrahamsen G, Sutharsan R, et al. Disease-specific, neurosphere-derived cells as models for brain disorders. Dis Model Mech 2010;3:785-798.

39. Teyssou E, Takeda T, Lebon V, et al. Mutations in SQSTM1 encoding p62 in amyotrophic lateral sclerosis: genetics and neuropathology. Acta Neuropathol 2013; 125:511-522.

40. Le Ber I, Camuzat A, Guerreiro R, et al. SQSTM1 mutations in French patients with frontotemporal dementia or frontotemporal dementia with amyotrophic lateral sclerosis. JAMA Neurol 2013;70:1403-1410. 


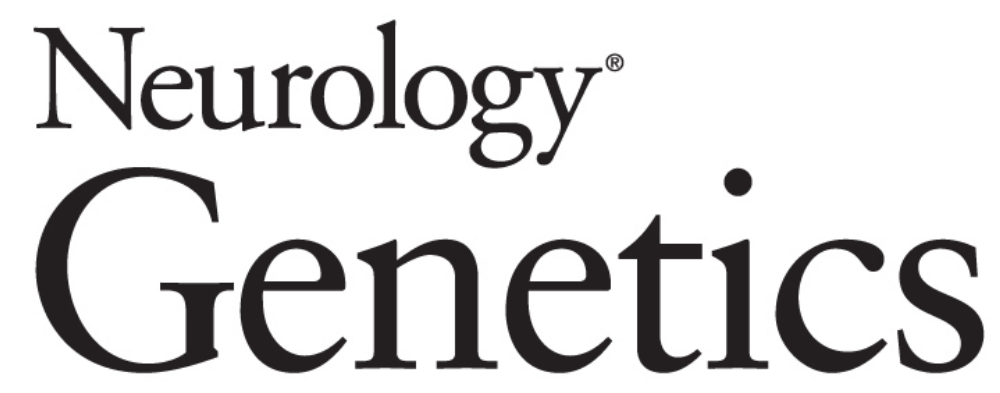

\section{Association of a structural variant within the SQSTM1 gene with amyotrophic lateral sclerosis}

Julia Pytte, Ryan S. Anderton, Loren L. Flynn, et al.

Neurol Genet 2020;6;

DOI 10.1212/NXG.0000000000000406

This information is current as of February 27, 2020

Neurol Genet is an official journal of the American Academy of Neurology. Published since April 2015, it is an open-access, online-only, continuous publication journal. Copyright Copyright ( 2020 The Author(s). Published by Wolters Kluwer Health, Inc. on behalf of the American Academy of Neurology.. All rights reserved. Online ISSN: 2376-7839.

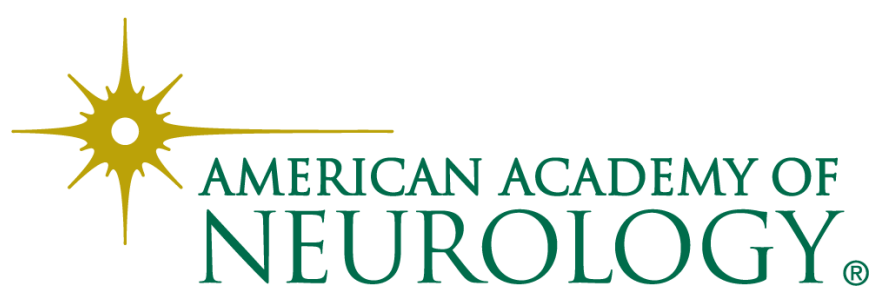




\section{Updated Information \& Services}

References

Citations

Subspecialty Collections

Permissions \& Licensing

Reprints including high resolution figures, can be found at: http://ng.neurology.org/content/6/2/e406.full.html

This article cites 38 articles, 4 of which you can access for free at: http://ng.neurology.org/content/6/2/e406.full.html\#\#ref-list-1

This article has been cited by 1 HighWire-hosted articles: http://ng.neurology.org/content/6/2/e406.full.html\#\#otherarticles

This article, along with others on similar topics, appears in the following collection(s):

\section{All Genetics}

http://ng.neurology.org//cgi/collection/all_genetics

All Neuromuscular Disease

http://ng.neurology.org//cgi/collection/all_neuromuscular_disease

Amyotrophic lateral sclerosis

http://ng.neurology.org//cgi/collection/amyotrophic_lateral_sclerosis_ Association studies in genetics

http://ng.neurology.org//cgi/collection/association_studies_in_genetics

Information about reproducing this article in parts (figures,tables) or in its entirety can be found online at:

http://ng.neurology.org/misc/about.xhtml\#permissions

Information about ordering reprints can be found online:

http://ng.neurology.org/misc/addir.xhtml\#reprintsus

Neurol Genet is an official journal of the American Academy of Neurology. Published since April 2015, it is an open-access, online-only, continuous publication journal. Copyright Copyright ( 2020 The Author(s). Published by Wolters Kluwer Health, Inc. on behalf of the American Academy of Neurology.. All rights reserved. Online ISSN: 2376-7839.

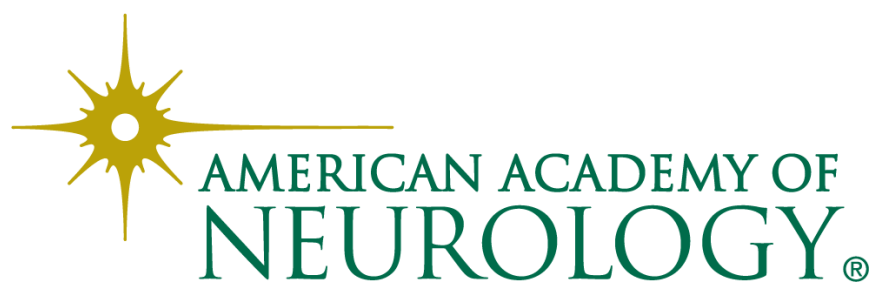

